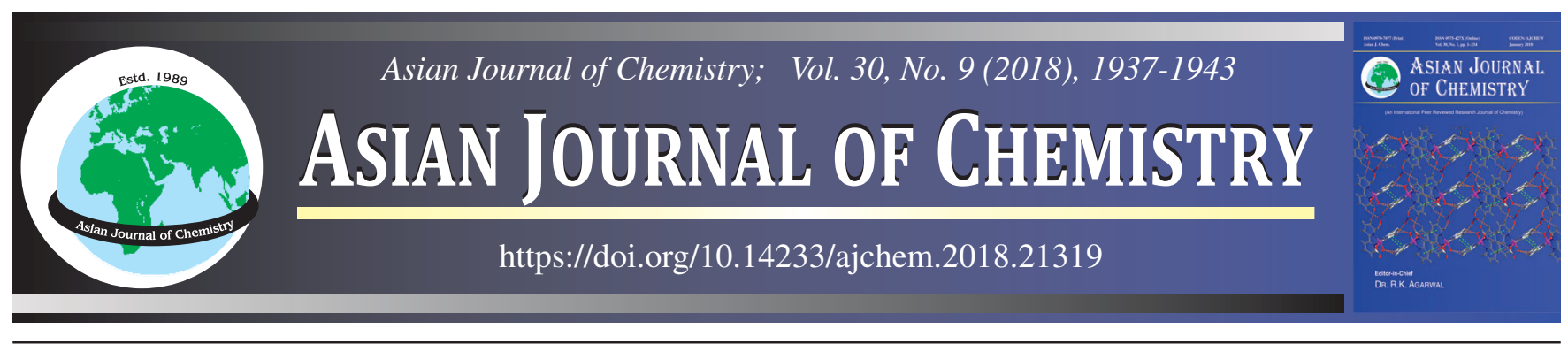

\title{
On the Homographic Dependence of Activation Energy and Viscosity Arrhenius' Temperature for Some Pure Fluids
}

\author{
N.O. Alzamel ${ }^{1, *}$, F. Alakhras ${ }^{1}$, A.A. Al-Arfaj ${ }^{1}$, M.A. Al-Khaldi ${ }^{1}$, \\ N.A. Al-OMAir ${ }^{1}$, E. Al-AbBaD ${ }^{1}$,A.A. WASSEL ${ }^{1}$ and N. OuerFelli ${ }^{1,2}$
}

${ }^{1}$ Imam Abdurrahman Bin Faisal University, Department of Chemistry, College of Science, P.O. Box 1982, Dammam 31441, Saudi Arabia ${ }^{2}$ Université de Tunis El Manar, Laboratoire de Biophysique et Technologies Médicales, LR13ES07, Institut Supérieur des Technologies Médicales de Tunis, 9 Avenue Dr. Zouhaier Essafi 1006 Tunis, Tunisia

*Corresponding author: E-mail: nalzamil@iau.edu.sa

Received: 6 March 2018; Accepted: 10 May 2018;

Published online: 31 July 2018

AJC-18999

\begin{abstract}
Viscosity is the most important hydraulic fluid characteristic and it is one of the significant quantities which are affected by pressure and temperature. Using of statistical methods for regression and correlation analysis, any eventual causal association between the melting and boiling points and the Arrhenius-type equation parameters of some classical Newtonian fluids is attempted. Empirical validations using 101 data set of viscosity of pure Newtonian fluids studied at atmospheric pressure and at different temperature domains give reliable statistical result. In fact, we found a significant strong causal correlation between the Arrhenius activation energy ( $\mathrm{E}_{\mathrm{a}}$ ), the boiling point $\left(\mathrm{T}_{\mathrm{b}}\right)$ and the Arrhenius temperature $\left(\mathrm{T}_{\mathrm{A}}\right)$. As a result, an original empirical model modeling this relationship is suggested. The proposed model allows the prediction of the normal boiling temperature through information on viscosity Arrhenius parameters. Moreover, the proposed model is very beneficial for fluid engineering data especially for the study of systems efficiency and hydraulic components Because of that, the need for more accurately and specific mathematical modeling of the fluid behaviour is required.
\end{abstract}

Keywords: Viscosity, Arrhenius temperature, Boiling point, Pure fluid.

ᄂ - - - - - - - - - - - - - - - - - - - - - - - - - - - - -

\section{INTRODUCTION}

Recently we have initiated a collaborating research axis on application of thermodynamic/transport properties of some engineering fluid systems in suggested correlation equations [1-11]. Considering the experimental values in the literature, here it is extended to investigate the viscosity Arrhenius behaviour along with a new parameter applied as Arrhenius temperature $\left(\mathrm{T}_{\mathrm{A}}\right)$, in some classical fluids at different temperatures.

In addition, we add that correlation between Arrhenius parameters reveals interesting Arrhenius temperature which is closely related to the vaporization temperature in the liquid vapour equilibrium and the limiting corresponding partial molar properties can permit us to estimate the boiling points of the pure components. In conclusion, we can ascertain that with more mathematical handlings, we will be able to reveal some physical significances of the viscosity Arrhenius parameters and it definitely develops as well as improves the thermodynamic theories and also to predict some information on liquid-vapour diagram through the study of the viscosity versus temperature and molar fraction only in the liquid phase of binary mixture.

The additional study on the eventual relationship between the Arrhenius temperature and the properties of great number binary mixtures can prove how the method predicts the properties of other non-treated fluid mixtures. This will be very fruitful for hydraulic fluid quantities simulation in the optimization and design of various industrial processes, such as in chemical industry, food industry, hydraulic-mechanics cosmetics and pharmaceuticals, etc.

\section{Temperature dependence of fluid viscosity}

Numerous empirical expressions have been suggested in the literature for representing the fluid viscosity $(\eta)$ versus temperature $(\mathrm{T})$ through available experimental data for interpolation purpose. Generally, most of these proposed simplified mathematical and practical models use at least two parameters.

This is an open access journal, and articles are distributed under the terms of the Creative Commons Attribution-NonCommercial 4.0 International (CC BY-NC 4.0) License, which allows others to copy and redistribute the material in any medium or format, remix, transform, and build upon the material, as long as appropriate credit is given and the new creations are licensed under the identical terms. 
The simplest form of representation of Newtonian fluid viscosity versus temperature is a relationship with two parameters proposed [12-15] and known as the Andrade equation:

$$
\eta=A e^{\frac{B}{T}}
$$

where A and B are positive constants and are characteristics of each pure liquid. Based on the Andrade equation, many researchers have suggested (quite similar) expressions. However, the most popular is the so called Arrhenius type-equation which may be linearly expressed in the natural logarithm form as follows:

$$
\ln \eta=\ln A_{s}+\frac{E_{a}}{R}\left(\frac{1}{T}\right)
$$

where $\mathrm{R}, \mathrm{E}_{\mathrm{a}}$ and $\mathrm{A}_{\mathrm{s}}$ are the ideal gas constant, the Arrhenius activation energy and the pre-exponential factor of the Arrhenius equation for the pure liquid system respectively.

In this work, we focus on the Arrhenius type-equation for studying any eventual relationship between its parameters and the melting and boiling points of some classical Newtonian liquids. If this relationship exists, it may allow to suggest new equation allowing the prediction of the boiling temperature through information on viscosity Arrhenius parameters.

\section{Correlation analysis}

Arrhenius and temperature parameters: A sample of 101 experimental data provided from the literature [15-52] on viscosity of pure Newtonian fluids (Table-1) studied at different temperature ranges and at atmospheric pressure is used in this work in order to analyze the existence of any eventual causal correlation between the Arrhenius type-equation, as knowing the activation energy $\left(E_{a}\right)$ and the entropic factor $\left(\ln A_{s}\right)$ and eventually the melting temperature $\left(\mathrm{T}_{\mathrm{m}}\right)$ and boiling temperature $\left(T_{b}\right)$. Also, the present investigation includes additional parameters such as the Arrhenius activation temperature $\left(\mathrm{T}^{*}=\right.$ $\left.E_{a} / R\right)$ and the Arrhenius temperature $\left(T_{A}=-E_{a} / R \cdot \ln A_{s}\right)$ as defined in previous works [1-11].

The first statistical investigation (Table-2) of the mean of the above-mentioned temperature parameters gives the following classification:

TABLE-1

ARRHENIUS PARAMETERS OF SOME PURE LIQUIDS STUDIED LITERATURE, ARRHENIUS ACTIVATION ENERGY $\left(\mathrm{E}_{\mathrm{a}}\right)\left(\mathrm{kJ} \mathrm{mol}^{-1}\right)$, THE LOGARITHM OF THE ENTROPIC FACTOR OF ARRHENIUS (ln $\mathrm{A}_{\mathrm{s}}$ ) (Pa-s), THE ARRHENIUS TEMPERATURE $\left(\mathrm{T}_{\mathrm{A}}\right)(\mathrm{K})$,

\begin{tabular}{|c|c|c|c|c|c|c|c|}
\hline$\#$ & Pure component & $\mathrm{T}_{\mathrm{b}}(\mathrm{K})$ & $\mathrm{E}_{\mathrm{a}}\left(\mathrm{kJ} \mathrm{mol}^{-1}\right)$ & $\ln \mathrm{A}_{\mathrm{s}}$ & $\mathrm{T}_{\mathrm{A}}(\mathrm{K})$ & $\mathrm{E}_{\text {a calc. }}\left(\mathrm{kJ} \mathrm{mol}^{-1}\right)$ & Ref. \\
\hline 1 & $n$-Heptane & 371.15 & 8.6196 & -11.302 & 91.723 & 8.5536 & [15] \\
\hline 2 & $n$-Pentane & 309.25 & 6.0998 & -10.886 & 67.393 & 6.0669 & [15] \\
\hline 3 & Butyl alcohol & 390.85 & 19.114 & -13.689 & 167.94 & 20.632 & [15] \\
\hline 4 & Aniline & 457.28 & 19.997 & -13.564 & 177.32 & 20.293 & [15] \\
\hline 6 & Ethyl acetate & 350.15 & 9.9183 & -11.728 & 101.72 & 10.057 & [15] \\
\hline 7 & Benzene & 353.15 & 10.940 & -11.812 & 111.39 & 11.408 & [15] \\
\hline 8 & Diethyl ether & 307.75 & 7.5203 & -11.446 & 79.021 & 7.4716 & [15] \\
\hline 9 & Acetic acid & 391.15 & 11.213 & -11.308 & 119.26 & 12.027 & [15] \\
\hline 10 & Acetone & 329.20 & 7.4406 & -11.097 & 80.643 & 7.5055 & [15] \\
\hline 11 & Toluene & 383.75 & 9.0229 & -11.135 & 97.461 & 9.1682 & [15] \\
\hline 12 & $m$-Xylene & 412.25 & 8.7485 & -10.975 & 95.872 & 8.7694 & [15] \\
\hline 13 & Carbone tetrachloride & 349.87 & 10.329 & -11.152 & 111.39 & 11.457 & [15] \\
\hline 14 & Chlorobenzene & 405.15 & 8.7094 & -10.695 & 97.939 & 9.0651 & [15] \\
\hline 15 & ethylbenzene & 409.15 & 9.1110 & -11.027 & 99.375 & 9.2111 & [15] \\
\hline 16 & $o$-Xylene & 417.15 & 9.8360 & -11.145 & 106.14 & 9.9866 & [15] \\
\hline 17 & Water & 373.15 & 15.835 & -13.414 & 141.98 & 16.057 & [16] \\
\hline 18 & Benzene & 353.15 & 5.5473 & -9.7233 & 68.618 & 5.9968 & [17] \\
\hline 19 & Chlorobenzene & 405.15 & 8.2327 & -10.452 & 94.732 & 8.6799 & [17] \\
\hline 20 & Water & 373.15 & 12.043 & -11.900 & 121.71 & 12.660 & [18] \\
\hline 21 & Benzyl alcohol & 478.45 & 26.777 & -16.486 & 195.34 & 23.135 & [19] \\
\hline 22 & Ethylamine & 289.75 & 20.025 & -15.048 & 160.05 & 25.063 & [19] \\
\hline 23 & $n$-Octanol & 468.15 & 24.955 & -14.945 & 200.83 & 24.652 & [20] \\
\hline 24 & Propylene glycol & 461.35 & 47.765 & -22.128 & 259.62 & 41.731 & [21] \\
\hline 25 & Butane-1,4-diol & 503.15 & 33.359 & -16.210 & 247.51 & 34.193 & [22] \\
\hline 26 & Butane-1,2-diol & 465.15 & 43.910 & -20.681 & 255.36 & 39.780 & [22] \\
\hline 27 & TEGMBE* & 545.15 & 22.963 & -14.119 & 195.60 & 21.375 & [23] \\
\hline 28 & 1,4-Butanediol & 503.15 & 33.904 & -16.438 & 248.07 & 34.346 & [24] \\
\hline 29 & 1,4-Butanediol & 503.15 & 34.033 & -16.485 & 248.31 & 34.412 & [24] \\
\hline 30 & 1,2-Butanediol & 465.15 & 45.933 & -21.510 & 256.84 & 40.299 & [24] \\
\hline 31 & 1,2-Butanediol & 465.15 & 46.763 & -21.857 & 257.32 & 40.469 & [24] \\
\hline 32 & Propylene glycol & 461.35 & 37.551 & -18.266 & 247.25 & 37.417 & [24] \\
\hline 33 & Tetrahydrofuran & 339.15 & 6.9072 & -10.474 & 79.310 & 7.2761 & [25] \\
\hline 34 & 1-Butanol & 390.85 & 19.742 & -13.925 & 170.52 & 21.195 & [25] \\
\hline 35 & 2-Butanol & 372.15 & 24.852 & -15.860 & 188.46 & 26.769 & [25] \\
\hline 36 & 1-Chlorobutane & 351.65 & 7.2626 & -10.699 & 81.639 & 7.4718 & [25] \\
\hline 37 & N,N-Dimethylformamide & 425.00 & 9.0530 & -10.780 & 101.00 & 9.2970 & [26] \\
\hline 38 & Formamide & 483.15 & 16.410 & -12.442 & 158.63 & 16.546 & [26] \\
\hline
\end{tabular}
THE BOILING POINT $\left(\mathrm{T}_{\mathrm{b}}\right)(\mathrm{K})$ AND CALCULATED VALUES FROM THE eqn. 4 


\begin{tabular}{|c|c|c|c|c|c|c|c|}
\hline 39 & N,N-Dimethylacetamide & 438.55 & 9.7590 & -10.914 & 107.54 & 9.9946 & {$[26]$} \\
\hline 40 & 2-Methoxyethanol & 397.65 & 15.185 & -12.602 & 144.93 & 15.977 & {$[27]$} \\
\hline 41 & Water & 373.15 & 15.510 & -13.284 & 140.42 & 15.774 & {$[27]$} \\
\hline 42 & N,N-Dimethylacetamide & 438.55 & 9.4260 & -10.896 & 104.05 & 9.5714 & {$[27]$} \\
\hline 43 & 2-Ethoxyethanol & 408.15 & 15.803 & -12.682 & 149.87 & 16.592 & {$[28]$} \\
\hline 44 & N,N-Dimethylacetamide & 438.55 & 9.7973 & -10.934 & 107.77 & 10.023 & [28] \\
\hline 45 & 1,4-Dioxane & 374.15 & 12.660 & -11.853 & 128.47 & 13.710 & [29] \\
\hline 46 & Water & 373.15 & 15.920 & -13.443 & 142.43 & 16.139 & [29] \\
\hline 47 & Isobutyric acid & 426.65 & 11.126 & -11.200 & 119.48 & 11.634 & {$[30]$} \\
\hline 48 & Water & 373.15 & 15.749 & -13.383 & 141.54 & 15.976 & {$[30]$} \\
\hline 49 & Ethanol & 351.15 & 13.204 & -12.166 & 130.50 & 14.552 & [31] \\
\hline 50 & Water & 373.15 & 15.433 & -13.232 & 140.28 & 15.749 & [31] \\
\hline 51 & Methanol & 337.75 & 9.9340 & -11.528 & 103.64 & 10.486 & [32] \\
\hline 52 & Water & 373.15 & 15.640 & -13.334 & 141.07 & 15.891 & [32] \\
\hline 53 & Methyl benzoate & 475.75 & 15.142 & -12.404 & 146.82 & 14.879 & [33] \\
\hline 54 & Cyclohexane & 353.89 & 14.461 & -12.831 & 135.56 & 15.395 & [33] \\
\hline 55 & $n$-Hexane & 341.88 & 9.1501 & -11.798 & 93.281 & 9.0037 & [33] \\
\hline 56 & Heptane & 371.15 & 11.292 & -12.367 & 98.023 & 9.3471 & [33] \\
\hline 57 & Octane & 398.75 & 13.275 & -12.886 & 123.90 & 12.599 & [33] \\
\hline 58 & $p$-Xylene & 411.15 & 8.3920 & -10.761 & 93.800 & 8.5322 & [34] \\
\hline 59 & Dimethyl sulfoxide & 462.15 & 14.058 & -11.872 & 142.42 & 14.424 & [34] \\
\hline 60 & $o$-Xylene & 417.15 & 9.5730 & -11.044 & 104.26 & 9.7519 & [35] \\
\hline 61 & Dimethyl sulfoxide & 462.15 & 14.333 & -12.002 & 143.63 & 14.602 & [35] \\
\hline 62 & Ethylene glycol & 470.15 & 29.941 & -16.146 & 223.03 & 29.762 & [36] \\
\hline 63 & 1,4-Dioxane & 374.15 & 11.669 & -11.430 & 122.78 & 12.808 & [36] \\
\hline 64 & Water & 373.15 & 16.684 & -13.742 & 146.02 & 16.807 & [36] \\
\hline 65 & Triethyl amine & 361.95 & 8.2120 & -11.248 & 87.810 & 8.1423 & [37] \\
\hline 66 & Water & 373.15 & 15.786 & -13.389 & 141.80 & 16.024 & {$[38]$} \\
\hline 67 & Glycerol & 455.15 & 59.608 & -24.143 & 296.95 & 60.270 & [39] \\
\hline 68 & TEGMME** & 395.15 & 21.245 & -13.638 & 187.36 & 24.975 & [40] \\
\hline 69 & $n$-Heptane & 371.15 & 14.344 & -12.613 & 136.78 & 15.176 & [41] \\
\hline 70 & Propargyl alcohol & 387.65 & 15.105 & -12.607 & 144.10 & 16.069 & [42] \\
\hline 71 & Allyl alcohol & 370.15 & 15.305 & -12.866 & 143.07 & 16.339 & [42] \\
\hline 72 & $t$-Butanol & 355.55 & 32.029 & -18.476 & 208.50 & 35.392 & [42] \\
\hline 73 & 2-Propanol & 355.15 & 21.950 & -15.032 & 175.63 & 24.353 & [42] \\
\hline 74 & 1-Propanol & 370.15 & 17.792 & -13.415 & 159.51 & 19.639 & [42] \\
\hline 75 & Methanol & 337.75 & 10.298 & -11.654 & 106.27 & 10.873 & [43] \\
\hline 76 & Ethanol & 351.15 & 12.309 & -11.830 & 125.14 & 13.625 & [43] \\
\hline 77 & $n$-Propanol & 370.15 & 17.786 & -13.407 & 159.56 & 19.649 & [43] \\
\hline 78 & Pyridine & 388.55 & 14.925 & -12.635 & 142.08 & 15.693 & [43] \\
\hline 79 & Bromobenzene & 429.15 & 16.771 & -13.450 & 149.98 & 16.153 & [44] \\
\hline 80 & Chlorobenzene & 405.15 & 7.9331 & -10.406 & 91.687 & 8.3215 & [44] \\
\hline 81 & Ethylbenzene & 409.15 & 8.5016 & -10.807 & 94.617 & 8.6406 & [44] \\
\hline 82 & Benzene & 353.15 & 14.955 & -13.254 & 135.71 & 15.443 & [44] \\
\hline 83 & Dimethylsulfoxide & 462.15 & 11.721 & -10.975 & 128.44 & 12.467 & [44] \\
\hline 84 & 3-Amino-1-propanol & 458.65 & 36.059 & -18.036 & 240.46 & 35.486 & {$[45]$} \\
\hline 85 & Isoamyl alcohol & 403.15 & 21.640 & -14.322 & 181.72 & 23.187 & [45] \\
\hline 86 & 2-Propanol & 355.15 & 25.430 & -16.403 & 186.46 & 27.526 & [45] \\
\hline 87 & Ethanol & 351.15 & 15.680 & -12.997 & 145.10 & 17.324 & [45] \\
\hline 88 & 1,4-Dioxane & 374.15 & 12.074 & -11.607 & 125.11 & 13.173 & [45] \\
\hline 89 & $n-\mathrm{C}_{10} \mathrm{H}_{22}$ & 447.25 & 10.633 & -11.355 & 112.63 & 10.558 & [46] \\
\hline 90 & $n-\mathrm{C}_{20} \mathrm{H}_{42}$ & 616.25 & 18.630 & -12.675 & 176.78 & 17.367 & [46] \\
\hline 91 & $n-\mathrm{C}_{22} \mathrm{H}_{46}$ & 642.15 & 18.750 & -12.469 & 180.86 & 17.639 & [46] \\
\hline 92 & $n-\mathrm{C}_{24} \mathrm{H}_{50}$ & 664.55 & 18.962 & -12.253 & 186.13 & 18.113 & [46] \\
\hline 93 & N-Methylacetamide & 478.15 & 19.128 & -13.155 & 174.88 & 19.318 & [47] \\
\hline 94 & 2-Methoxyethanol & 397.65 & 14.504 & -12.662 & 137.77 & 14.770 & [47] \\
\hline 95 & Water & 373.15 & 15.568 & -13.307 & 140.70 & 15.824 & [47] \\
\hline 96 & Propylene carbonate & 513.15 & 14.192 & -11.729 & 145.53 & 14.234 & [48] \\
\hline 97 & 1,2-Diethoxyethane & 394.15 & 7.5690 & -10.819 & 84.142 & 7.5176 & [49] \\
\hline 98 & Acetonitrile & 354.65 & 6.9895 & -10.793 & 77.885 & 7.0171 & [50] \\
\hline 99 & 2-Methoxyethanol & 397.65 & 15.704 & -12.822 & 147.31 & 16.393 & [51] \\
\hline 100 & Tetrahydrofuran & 339.15 & 6.7382 & -10.393 & 77.977 & 7.1186 & [52] \\
\hline 101 & Methanol & 337.75 & 10.198 & -11.629 & 105.47 & 10.755 & [52] \\
\hline
\end{tabular}

*TEGMBE $=$ triethylene glycol monobutyl ether; $* *$ TEGMME $=$ triethylene glycol monomethyl ether 


$$
\overline{\mathrm{T}}_{\mathrm{A}}<\overline{\mathrm{T}}_{\mathrm{m}}<\overline{\mathrm{T}}_{\mathrm{b}}<\overline{\mathrm{T}}^{*}
$$

where there is no clear intersection between any consecutive (CI), Fig. 1 confirms this observation. Moreover, according to the coefficient of variation (CV), the Arrhenius activation temperature $\left(\mathrm{T}^{*}\right)$ is the most dispersed variable, inversely to the boiling temperature $\left(\mathrm{T}_{\mathrm{b}}\right)$ which is the most homogenous.

Correlation analysis: Firstly, we studied direct mutual correlation between the Arrhenius parameters $\left(\ln \mathrm{A}_{\mathrm{s}} \mathrm{E}_{\mathrm{a}}\right.$ and $\left.\mathrm{T}_{\mathrm{A}}\right)$. Fig. 2 shows that the pair-wise scatter plots are a suitable

\begin{tabular}{|c|c|c|c|c|}
\hline \multicolumn{5}{|c|}{$\begin{array}{c}\text { TABLE-2 } \\
\text { DESCRIPTIVE STATISTICS OF TEMPERATURES } \\
\text { PARAMETERS: ARITHMETIC MEAN }\left(\overline{\mathrm{T}}_{\mathrm{i}}\right), \\
\text { CONFIDENCE INTERVAL }(\mathrm{CI}), \text { STANDARD ERROR } \\
\text { (SE) AND COEFFICIENT OF VARIATION }(\mathrm{CV})\end{array}$} \\
\hline Parameters & $\overline{\mathrm{T}}_{\mathrm{i}}(\mathrm{K})$ & CI (mean) & SE & $\mathrm{CV}(\%)$ \\
\hline $\mathrm{T}_{\mathrm{A}}$ & 143.80 & $131.17-156.44$ & 5.029 & 36 \\
\hline $\mathrm{T}_{\mathrm{m}}$ & 227.16 & $217.32-240.69$ & 4.065 & 23 \\
\hline $\mathrm{T}_{\mathrm{b}}$ & 406.68 & $390.31-423.05$ & 6.514 & 16 \\
\hline $\mathrm{T}^{*}$ & 2012.88 & $1707.90-2317.90$ & 122.000 & 61 \\
\hline
\end{tabular}
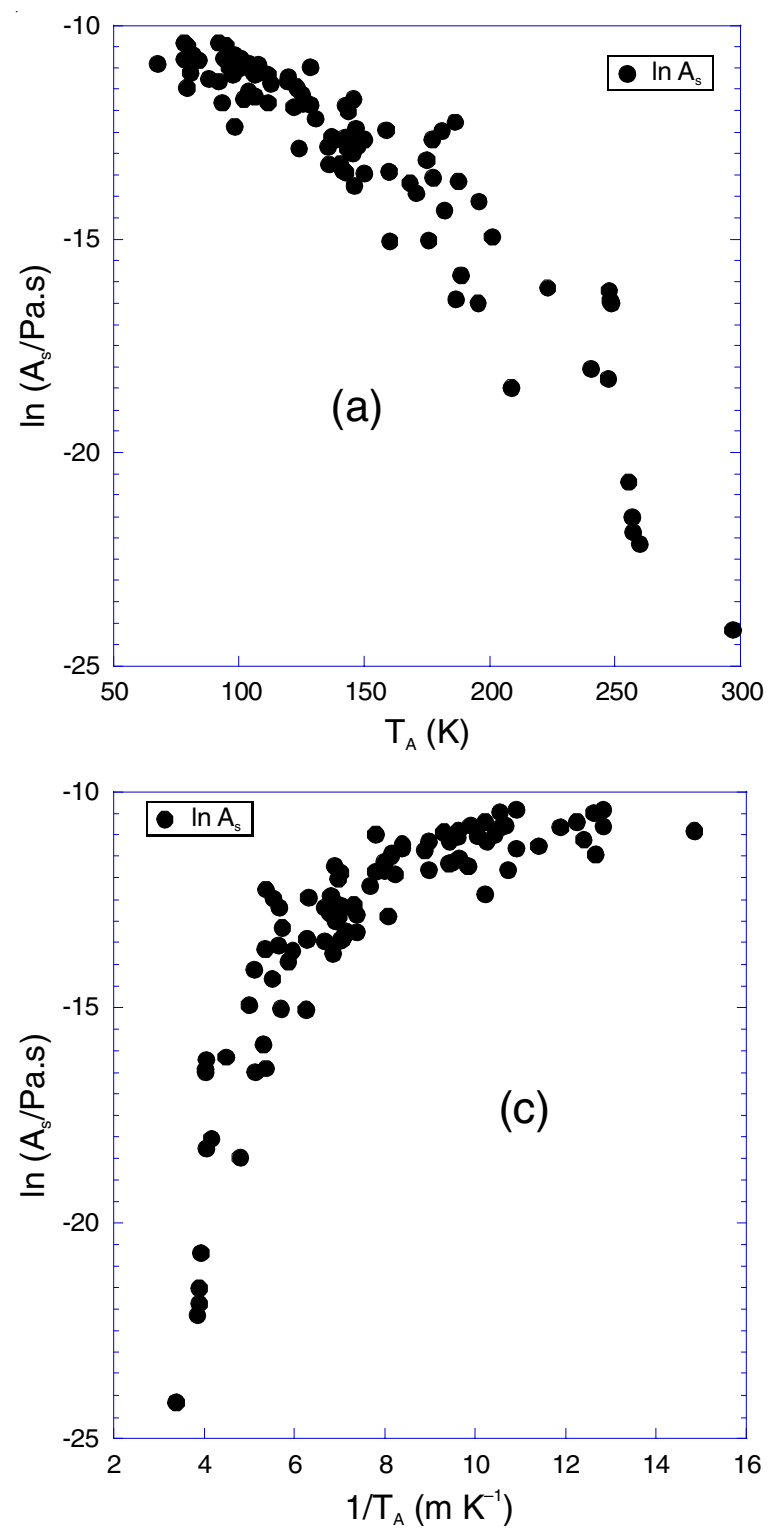

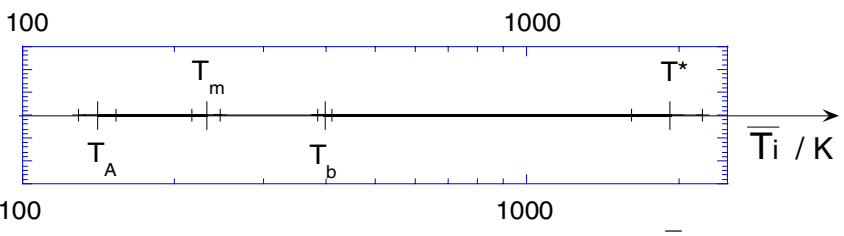

Fig. 1. Classification means of different temperatures $\left(\overline{\mathrm{T}}_{\mathrm{i}}\right)$ used in the present statistical investigation. Great vertical bar (l): the average; small vertical bar (I): delimitation of (CI)

graphical method to deduct any eventual correlation. Based on the graphs, we deduced that there is clear relationship between some of the pair-wise analysis. In fact, comparison between the scatter plots $(\mathrm{a}, \mathrm{c})$ and $(\mathrm{b}, \mathrm{d})$ of Fig. 2, we observe that the $\mathrm{T}_{\mathrm{A}^{-}}$ dependence of $\left(E_{a}\right)$ is "stronger" than of $\left(\ln A_{s}\right)$. In addition, comparison between the scatter plots (b) and (d) of Fig. 2, it is concluded that the $\left(1 / T_{A}\right)$-dependence of $\left(E_{a}\right)$ is more "net" than the $T_{A}$-dependence of $\left(E_{a}\right)$. So, in the light of these observations and especially the probable existence of vertical and horizontal asymptotes in Fig. 2d, we tested a suggested homographic dependence linking $\mathrm{Y}=\mathrm{E}_{\mathrm{a}}$ with $\mathrm{X}=\left(1 / \mathrm{T}_{\mathrm{A}}\right)$ expressed as follows:
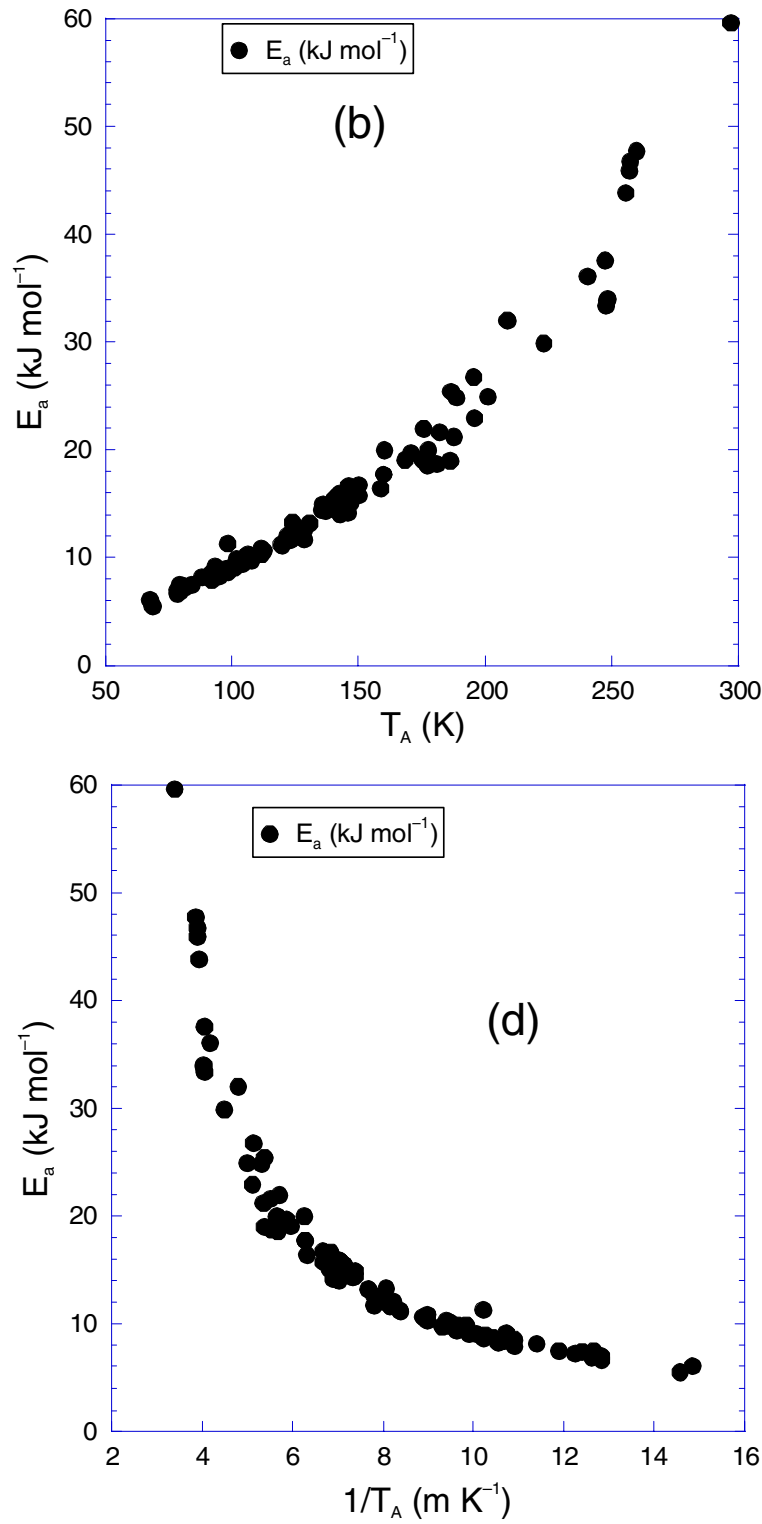

Fig. 2. Scatter plots of the direct mutual correlation between the Arrhenius parameters $\left(\ln A_{s}, E_{a}\right.$ and $\left.T_{A}\right)$ of some pure solvents 


$$
\mathrm{Y}=\frac{\mathrm{AX}+\mathrm{B}}{\mathrm{CD}+\mathrm{D}}
$$

To consider about the dependence of the viscosity with some physico-chemical properties, we have tested the boiling temperature $\left(T_{b}\right)$ which is already predicted through the temperature-dependence presented in previous works [1-11]. For that, in order to measure up and assess eventual relationship between the target parameters, we have carried out the Spearman's rank correlations tests [53], where the null hypothesis assumes the independence of the variables. Table- 3 presents the result of the test for three pairs.

\begin{tabular}{cccc}
\multicolumn{5}{c}{ TABLE-3 } \\
SPEARMAN RANK CORRELATION TESTS \\
\hline \multicolumn{2}{c}{ Parameters } & Spearman rho & Prob $>|\mathrm{t}|$ \\
\hline $\ln \mathrm{A}_{\mathrm{s}}$ & $\mathrm{T}_{\mathrm{b}}$ & -0.24 & 0.03 \\
$\mathrm{E}_{\mathrm{a}}$ & $\mathrm{T}_{\mathrm{b}}$ & 0.40 & 0.00 \\
$\mathrm{~T}_{\mathrm{A}}$ & $\mathrm{T}_{\mathrm{b}}$ & 0.47 & 0.00 \\
\hline
\end{tabular}

Nevertheless, we think that an implicit association probably exists. For that purpose, we have tried various possible relationships between two or more transformed parameters. In first step, we have found interesting relations for which Fig. 3 illustrates the two best correlations found in this primary investigation. Indeed, a strong nonlinear correlation exists between the viscosity activation energy $\mathrm{E}_{\mathrm{a}}$ and the boiling temperature $\left(\mathrm{T}_{\mathrm{b}}\right)$.

Thus, using non-linear regression method to determinate the expression which best fit this correlation, we propose the homographic dependence linking $\mathrm{Y}=\mathrm{E}_{\mathrm{a}}$ and $\mathrm{X}=\left(1 / \mathrm{T}_{\mathrm{A}}-1 / \mathrm{T}_{\mathrm{b}}\right)$ expressed by the eqn. 3 .

As a numerical application for the studied set of 101 solvents we suggest the eqn. 4 as a practical expression with correlation coefficient $\mathrm{R}=0.9935$, standard deviation $\mathrm{SD}=$ 1.26 and standard error $(\mathrm{SE})=0.16$.

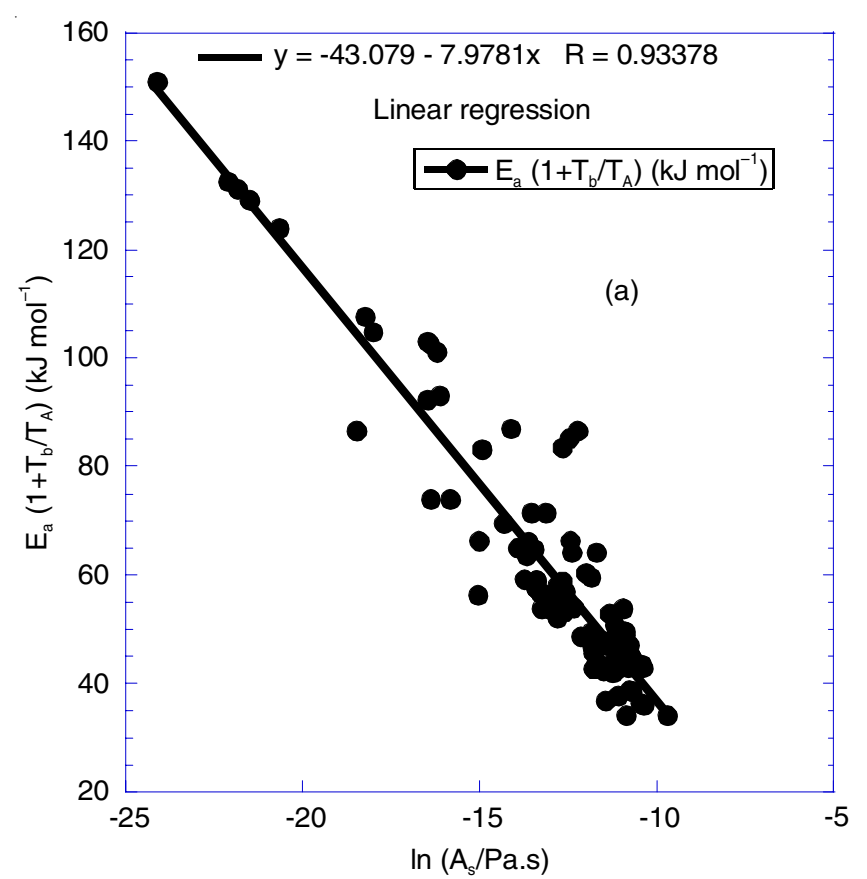

$$
\mathrm{E}_{\mathrm{a}}=\frac{0.07 \times\left(\frac{1}{\mathrm{~T}_{\mathrm{A}}}-\frac{1}{\mathrm{~T}_{\mathrm{b}}}\right)+69.5}{\left(\frac{1}{\mathrm{~T}_{\mathrm{A}}}-\frac{1}{\mathrm{~T}_{\mathrm{b}}}\right)-0.016}
$$

where $E_{a}$ is in $\mathrm{kJ} \mathrm{mol}^{-1}$ and $\mathrm{T}_{\mathrm{A}}$ and $\mathrm{T}_{\mathrm{b}}$ in $\mathrm{mK}$.

The calculated values of activation energies $\left(\mathrm{E}_{\mathrm{a}, \mathrm{cal}}\right)$ are presenteded in Table-2 and comparison between the experimental values $\left(\mathrm{E}_{\mathrm{a}, \mathrm{exp}}\right)$ are depicted by Fig. 4a,b. Nevertheless, the increase of absolute deviation of activation energy with the decrease of $\left(1 / T_{A}-1 / T_{b}\right)$ is not an inconvenient that because of the increase of the activation energy in the corresponding region (Fig. 3b).

Regarding the curvature shape of the scatter plots in Fig. $3 \mathrm{~b}$, we deduced interesting result. A strong hyperbolic correlation (eqns. 3 and 4$)$ may exist between $E_{a}$ and $\left(1 / T_{A}-1 / T_{b}\right)$. For that, the following expression (eqn. 5) linking $\mathrm{E}_{\mathrm{a}}$ with $\left(1 / \mathrm{T}_{\mathrm{A}^{-}}\right.$ $1 / T_{b}$ ) may hold well and releases some physical significance or equation's parameters:

$$
\mathrm{E}_{\mathrm{a}}=\frac{\mathrm{R} \cdot \omega}{\left(\frac{1}{\mathrm{~T}_{\mathrm{A}}}-\frac{1}{\mathrm{~T}_{\mathrm{b}}}\right)-\frac{1}{\tau}}+\varepsilon_{0}
$$

where $\omega$ is dimensionless constant, $\mathrm{R}$ is the ideal gas constant, $\tau$ is equivalent to an absolute temperature statistically related to the minimal values that the difference between the reciprocal of Arrhenius and boiling temperatures can theoretically taken for the set of treated solvents' group and $\varepsilon_{0}$ is equivalent to the minimal energy value that the Arrhenius activation energy can theoretically taken for the set of studied of viscous fluids.

According to the Table-4, which presents the result of statistical estimation of the proposed model, the estimated parameters are statistically significant, the R-squared is near to one and the value of Fisher statistics is high [54]. The present

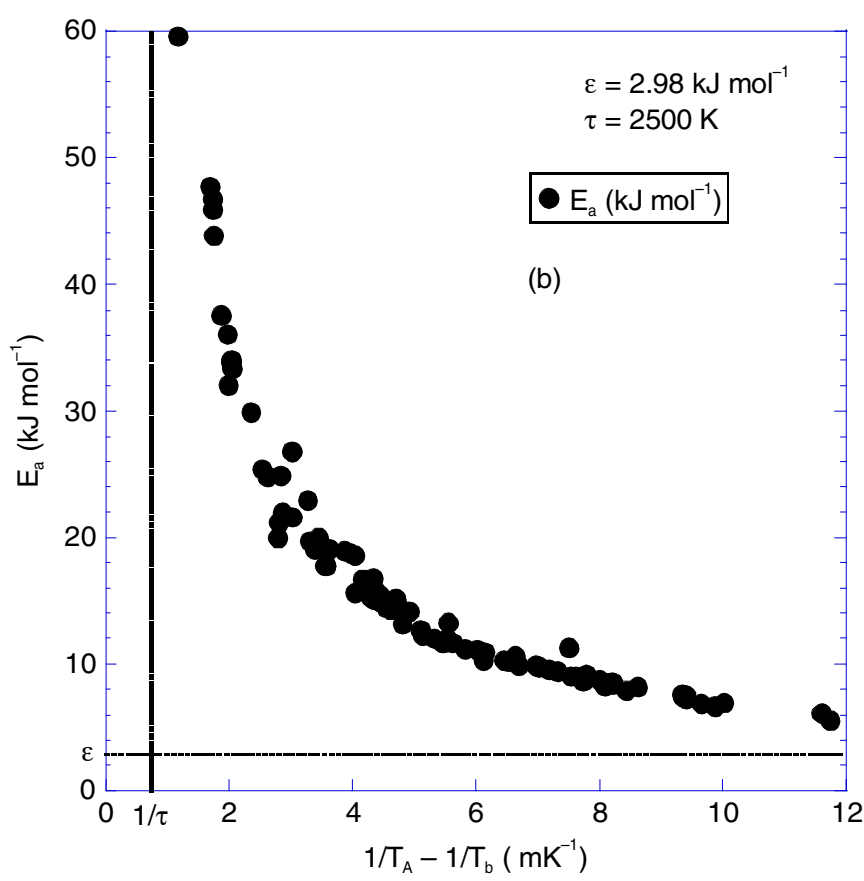

Fig. 3. Correlations between arrhenius parameters $\left(E_{a}\right)$ or $\left(\ln A_{s}\right)$ and some transformed variables for some pure classical solvents [Ref. 15-52] 

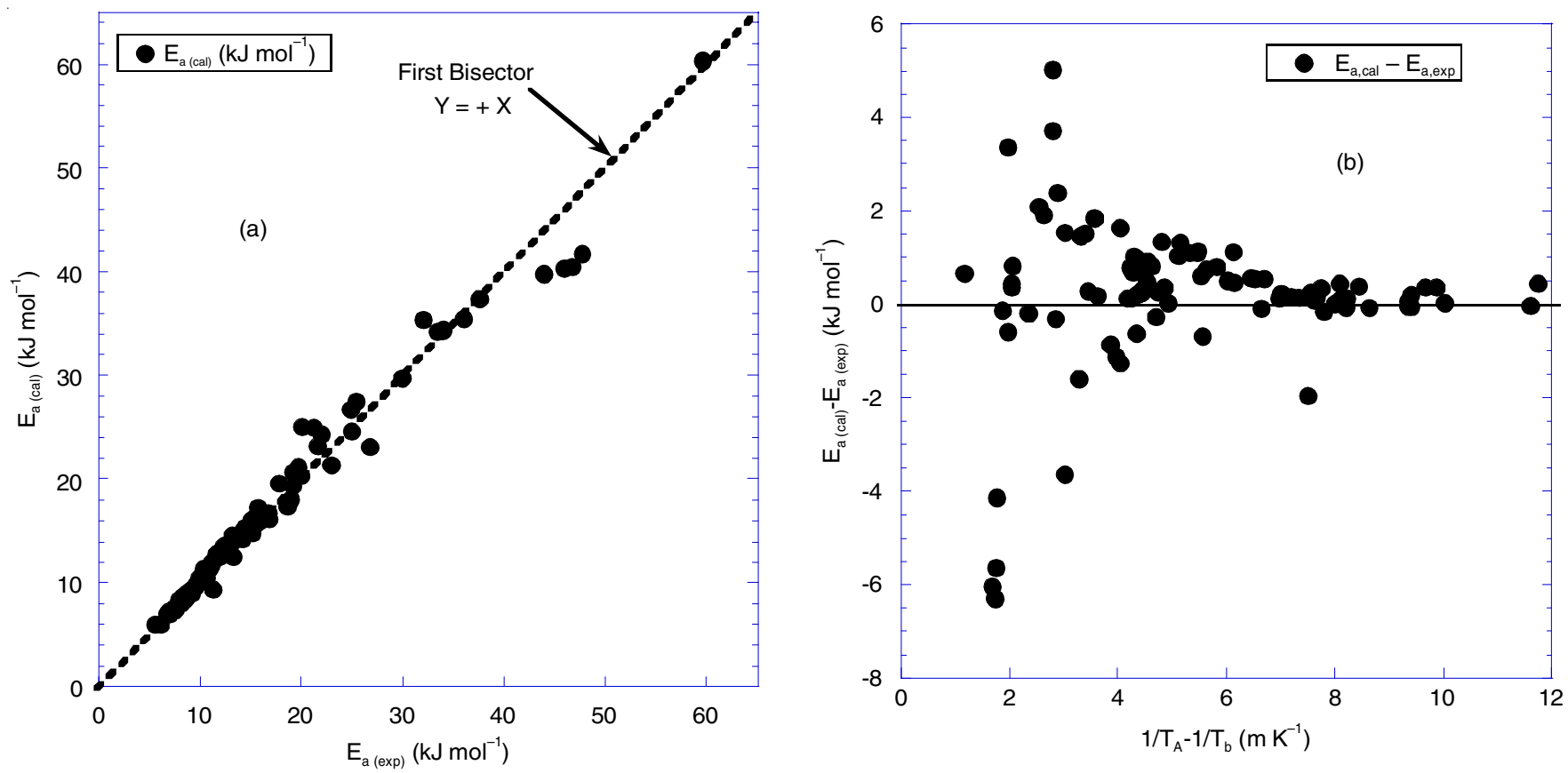

Fig. 4. Graphical comparison between the experimental $\left(\mathrm{E}_{\mathrm{a}, \mathrm{exp}}\right)$ and the estimated $\left(\mathrm{E}_{\mathrm{a}, \mathrm{cal}}\right)$ values of activation energies for some pure classical solvents [Ref. 15-52]

\begin{tabular}{|c|c|c|c|c|c|}
\hline \multicolumn{6}{|c|}{$\begin{array}{c}\text { TABLE-4 } \\
\text { RESULT OF STATISTICAL ESTIMATIONS OF THE eqn. } 5\end{array}$} \\
\hline \multirow{2}{*}{ Eqn. } & \multicolumn{3}{|c|}{ Parameter } & \multirow{2}{*}{$\begin{array}{c}\mathrm{R}- \\
\text { squared }\end{array}$} & \multirow{2}{*}{$\begin{array}{c}\text { F- } \\
\text { statistics }\end{array}$} \\
\hline & $\omega$ & $\tau(\mathrm{K})$ & $\varepsilon_{0}\left(\mathrm{~kJ} \mathrm{~mol}^{-1}\right)$ & & \\
\hline 3 & $\begin{array}{c}8.13 \\
(6.50) \\
\end{array}$ & $\begin{array}{c}2500 \\
(32.78)\end{array}$ & $\begin{array}{c}2.98 \\
(25.75)\end{array}$ & 0.998 & 7678 \\
\hline
\end{tabular}

result allows as expecting a very predictive quality of approximation during their practical application.

Finally, regarding the new concept of boiling temperature prediction through the temperature-dependence of dynamic found in previous works [1-11] and the mutual correlation between the two Arrhenius parameters $\left(\mathrm{E}_{\mathrm{a}}\right)$ and $\left(\ln \mathrm{A}_{\mathrm{s}}\right)$ presented in earlier works [55,56], a 3D global view (Fig. 5) of graphical correlations between Arrhenius parameters and the boiling temperature of the set of studied classical solvents well confirms the investigated causal correlation presented in the present and previous works. We add that the quasi-linear dependence between the reciprocal Arrhenius temperature $\left(1 / T_{A}\right)$ and the transformed variable $\left(1 / T_{A}-1 / T_{b}\right)$ observed in Fig. 5, is none other than the statistical conflict between the endogenous and exogenous variables and not a real causal correlation.

\section{Conclusion}

Statistical methods are applied for the regression and correlation analysis for investigating the existence of any eventual causal correlation between the Arrhenius-type equation parameters and the boiling points of some classical Newtonian fluids. 101 data set of viscosity of pure Newtonian fluids studied at different temperature and at atmospheric pressure from the literature is utilized for empirical analysis. A significant strong nonlinear correlation between the boiling point $\left(T_{b}\right)$, the Arrhenius activation energy $\left(E_{a}\right)$ and the Arrhenius

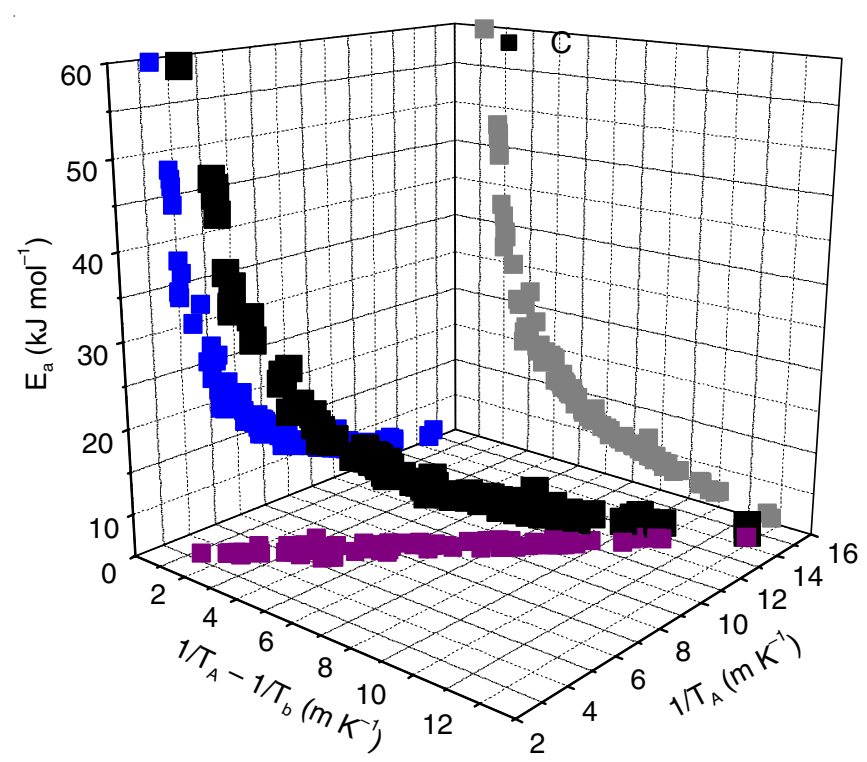

Fig. 5. 3D graphical correlations between Arrhenius activation energy $\left(E_{a}\right)$, the reciprocal Arrhenius temperature $\left(1 / \mathrm{T}_{\mathrm{A}}\right)$ and the transformed variable $\left(1 / T_{A}-1 / T_{b}\right)$ for some pure classical solvents [Ref. 15-52]

temperature $\left(\mathrm{T}_{\mathrm{A}}\right)$ is observed. In conclusion, we have proposed an empirical equation modeling of this relationship.

After all, for practical use and for giving some physical meaning to the suggested empirical model, to be fruitful for fluids engineering. We have made some variables transformations to obtain new semi-empirical models, which may be interesting for the theoreticians. This result is important given that the suggested equation allows the prediction of the boiling point only through information on viscosity Arrhenius parameters in Newtonian liquid state. Moreover, the suggested equation is very useful for engineering data especially for the study of systems efficiency and hydraulic components. 


\section{CONFLICT OF INTEREST}

The authors declare that there is no conflict of interests regarding the publication of this article.

\section{REFERENCES}

1. N.A. Al-Omair, D. Das, L. Snoussi, B. Sinha, R. Pradhan, K. Acharjee, K. Saoudi and N. Ouerfelli, Phys. Chem. Liq., 54, 615 (2016); https://doi.org/10.1080/00319104.2016.1139707.

2. M. Dallel, A.A. Al-Zahrani, H.M. Al-Shahrani, G.M. Al-Enzi, L. Snoussi, N. Vrinceanu, N.A. Al-Omair and N. Ouerfelli, Phys. Chem. Liq., 55, 541 (2017); https://doi.org/10.1080/00319104.2016.1233181.

3. M. Dallel, A.A. Al-Arfaj, N.A. Al-Omair, M.A. Alkhaldi, N.O. Alzamel, A.A. Al-Zahrani and N. Ouerfelli, Asian J. Chem., 29, 2038 (2017); https://doi.org/10.14233/ajchem.2017.20764.

4. H. Salhi, N.A. Al-Omair, A.A. Al-Arfaj, M.A. Alkhaldi, N.O. Alzamel, K.Y. Alqahtani and N. Ouerfelli, Asian J. Chem., 28, 1972 (2016); https://doi.org/10.14233/ajchem.2016.19858.

5. M. Hichri, D. Das, A. Messaâdi, E.S.B.H. Hmida, N. Ouerfelli and I. Khattech, Phys. Chem. Liq., 51, 721 (2013); https://doi.org/10.1080/00319104.2013.802210.

6. Z. Trabelsi, M. Dallel, H. Salhi, D. Das, N.A. Al-Omair and N. Ouerfelli, Phys. Chem. Liq., 53, 529 (2015); https://doi.org/10.1080/00319104.2014.947372.

7. A. Messaâdi, H. Salhi, D. Das, N.O. Alzamil, M.A. Alkhaldi, N. Ouerfelli and A.H. Hamzaoui, Phys. Chem. Liq., 53, 506 (2015); https://doi.org/10.1080/00319104.2015.1007980.

8. D. Das, H. Salhi, M. Dallel, Z. Trabelsi, A.A. Al-Arfaj and N. Ouerfelli, J. Solution Chem., 44, 54 (2015); https://doi.org/10.1007/s10953-014-0289-6.

9. N. Dhouibi, M. Dallel, D. Das, M. Bouaziz, N. Ouerfelli and A.H. Hamzaoui, Phys. Chem. Liq., 53, 275 (2015); https://doi.org/10.1080/00319104.2014.972552.

10. H. Salhi, M. Dallel, Z. Trabelsi, N.O. Alzamil, M.A. Alkhaldi and N. Ouerfelli, Phys. Chem. Liq., 53, 117 (2015); https://doi.org/10.1080/00319104.2014.956170.

11. M.A. Alkhaldi, Phys. Chem. Liq., 56, 250 (2018); https://doi.org/10.1080/00319104.2017.1327582.

12. C.R. Duhne, Chem. Eng., 86, 83 (1979).

13. D.S. Viswanath and G. Natarajan, Databook on Viscosity of Liquids, Hemisphere: New York (1989).

14. J.A. Dean, Handbook of Organic Chemistry. McGraw-Hill: New York (2004).

15. D.S. Viswanath, T.K. Ghosh, G.H.L. Prasad, N.V.K. Dutt and K.Y. Rani, Viscosity of Liquids. Theory, Estimation, Experiment and Data, Springer: Dordrecht, The Netherlands. (2007).

16. B.B. Gurung and M.N. Roy, Phys. Chem. Liq., 45, 331 (2007) https://doi.org/10.1080/00319100600574143.

17. K. Saravanakumar and T.R. Kubendran, Res. J. Chem. Sci., 2, 50 (2012).

18. U. Dománska and M. Królikowska, J. Solution Chem., 41, 1422 (2012); https://doi.org/10.1007/s10953-012-9875-7.

19. C.M. Saxena, A. Saxena, A.K. Srivastava and N.K. Shukla, Am. Chem. Sci. J., 3, 468 (2013); https://doi.org/10.9734/ACSJ/2013/5229.

20. G.F. De Verteuil, The Viscosity of Liquids (a) Normal Octanol at Atmospheric Pressure (b) an Equipment for High Pressure, Thesis in Chemical Engineering, The University of British Columbia, Vancouver, Canada, (1958). http://hdl.handle.net/2429/40892.

21. G.O. Curme and F. Johnston, Viscosity of Aqueous Propylene Glycol Solutions, Curme and Johnston, Reinhold Publishing Corp., New York (1952).

22. G. Czechowski, A. Rabiega and J. Jadzyn, Z. Naturforschung, 58a, 569 (2003).

23. X.-X. Li, Y.-J. Hu and G. Liu, J. Chem. Eng. Data, 55, 1045 (2010); https://doi.org/10.1021/je900510x.

24. I.M. Smallwood, Handbook of Organic Solvent Properties, John Wiley \& Sons Inc., New York, Toronto (1996).
25. A. Mariano, A. Camacho, M. Postigo, A. Valen, H. Artigas, F.M. Royo and J.S. Urieta, Braz. J. Chem. Eng., 17, 459 (2000); https://doi.org/10.1590/S0104-66322000000400011.

26. D. Das, S.K. Ray and D.K. Hazra, J. Indian Chem. Soc., 80, 385 (2003).

27. P.J. Victor, D. Das and D.K. Hazra, J. Indian Chem. Soc., 81, 1045 (2004).

28. D. Das and D.K. Hazra, Indian J. Phys., 77B, 519 (2003).

29. N. Ouerfelli, Z. Barhoumi and O. Iulian, J. Solution Chem., 41, 458 (2012); https://doi.org/10.1007/s10953-012-9812-9.

30. N. Ouerfelli and M. Bouanz, J. Phys. Condens. Matter, 8, 2763 (1996); https://doi.org/10.1088/0953-8984/8/16/005.

31. R. Belda, J.V. Herráez and O. Diez, Phys. Chem. Liq., 42, 467 (2004); https://doi.org/10.1080/00319100410001700850.

32. S.Z. Mikhail and W.R. Kimel, J. Chem. Eng. Data, 6, 533 (1961); https://doi.org/10.1021/je60011a015.

33. M.V. Rathnam, S. Mankumare and M.S.S. Kumar, J. Chem. Eng. Data, 55, 1354 (2010) https://doi.org/10.1021/je9006597.

34. O. Ciocirlan and O. Iulian, J. Serb. Chem. Soc., 73, 73 (2008); https://doi.org/10.2298/JSC0801073C.

35. O. Ciocirlan and O. Iulian, J. Serb. Chem. Soc., 74, 317 (2009); https://doi.org/10.2298/JSC0903317C.

36. O. Ciocirlan and O. Iulian, Rev. Roum. Chim., 55, 45 (2010).

37. N. Hafaiedh, A. Toumi and M. Bouanz, J. Chem. Eng. Data, 54, 2195 (2009); https://doi.org/10.1021/je800982n.

38. A. Toumi, N. Hafaiedh and M. Bouanz, Fluid Phase Equilib., 278, 68 (2009); https://doi.org/10.1016/j.fluid.2009.01.004

39. J.B. Segur and H.E. Oberstar, J. Ind. Eng. Chem., 43, 2117 (1951); https://doi.org/10.1021/ie50501a040.

40. X.-X. Li, G.-C. Fan, Y.-W. Wang, M. Zhang and Y.-Q. Lu, J. Mol. Liq., 151, 62 (2010); https://doi.org/10.1016/j.molliq.2009.11.005.

41. C.K. Zéberg-Mikkelsen, G. Watson, A. Baylaucq, G. Galliéro and C. Boned, Fluid Phase Equilib., 245, 6 (2006); https://doi.org/10.1016/j.fluid.2006.01.030.

42. S. Akhtar, M.M.H. Bhuiyan, M.S. Uddin, B.S.M. Nessa and M.A. Saleh, Phys. Chem. Liq., 37, 215 (1999); https://doi.org/10.1080/00319109908035923.

43. E.D. Dikio, S.M. Nelana, D.A. Isabirye and E.E. Ebenso, Int. J. Electrochem. Sci., 7, 11101 (2012)

44. S. Parthasarathi, K. Saravanakuamr, R. Baskaran and T.R. Kubendran, Int. J. Sci. Technol., 1, 96 (2011).

45. A. Omrani, A.A. Rostami and M. Mokhtary, J. Mol. Liq., 157, 18 (2010); https://doi.org/10.1016/j.molliq.2010.07.015.

46. A.J. Queimada, I.M. Marrucho, J.A.P. Coutinho and E.H. Stenby, Int. J. Thermophys., 26, 47 (2005); https://doi.org/10.1007/s10765-005-2352-4.

47. P.J. Victor and D.K. Hazra, J. Chem. Eng. Data, 47, 79 (2002); https://doi.org/10.1021/je0101451.

48. P.K. Muhuri and D.K. Hazra, J. Chem. Eng. Data, 40, 582 (1995); https://doi.org/10.1021/je00019a008.

49. P.K. Muhuri and D.K. Hazra, J. Chem. Eng. Data, 39, 375 (1994); https://doi.org/10.1021/je00014a041.

50. N. Saha, B. Das and D.K. Hazra, J. Chem. Eng. Data, 40, 1264 (1995); https://doi.org/10.1021/je00022a026.

51. T.A. Salman, J. Al-Nahrain Univ. Sci., 11, 1 (2008); https://doi.org/10.22401/JNUS.11.3.01.

52. P.K. Muhuri, B. Das and D.K. Hazra, J. Chem. Eng. Data, 41, 1473 (1996); https://doi.org/10.1021/je960196b.

53. C. Spearman, Am. J. Psychol., 15, 72 (1904); https://doi.org/10.2307/1412159.

54. F. Wilcoxon, Biom. Bull., 1, 80 (1945); https://doi.org/10.2307/3001968.

55. R.B. Haj-Kacem, N. Ouerfelli, J.V. Herráez, M. Guettari, H. Hamda and M. Dallel, Fluid Phase Equilib., 383, 11 (2014); https://doi.org/10.1016/j.fluid.2014.09.023.

56. A. Messaâdi, N. Dhouibi, H. Hamda, F.B.M. Belgacem, Y.H. Adbelkader, N. Ouerfelli and A.H. Hamzaoui, J. Chem., Article ID 163262 (2015); https://doi.org/10.1155/2015/163262. 